\title{
Metabolization of lactic and acetic acids in Pecorino Romano cheese made with a combined starter of lactic acid bacteria and yeast
}

\author{
by \\ P. DEIANA*, F. FATICHENTI*, G. A. FARRIS*, \\ G. MOCQUOT**, Roberta LODI***, Rosanna TODESCO*** \\ and L. CECCHI***
}

\section{S u $\mathrm{m}$ m a ry}

Debaryomyces hansenii, added to the lactic acid bacteria starters in the production of Pecorino Romano cheese, developed even in the interior of the cheese wheels, consuming lactic and acetic acids. This behaviour is important in the nutritional inhibition of Clostridium tyrobutyricum and $C l$. butyricum. In the cheeses where yeast growth was greater, ripening was more accelerated, and quality was very good; the final product was typical.

This investigation was supported by a grant received from the Consiglio Nazionale delle Ricerche (C.N.R.) Roma.

Key words: Cheese - Bacteria starters - Yeast - Ripening.

\section{INTRODUCTION}

Debaryomyces hansenii is a typical milk and cheese yeast, acting synergically with the lactic microflora. It has good proteolytic and

* Istituto di Microbiologia Agraria e Tecnica dell'Università degli Studi di Sassari.

** I.N.R.A. Centre National de Recherches Zootechniques - Jouy-en-Josas.

*** Centro per lo Studio Tecnologico, Bromatologico e Microbiologico del Latte C.N.R. - Università di Milano. 
lipolytic properties and, in the correct proportion, is useful in the overall ripening of some cheese varieties (Deiana et al., 1977; Devoyod and Sponem, 1970; Fatichenti et al., 1977; Georgantas, 1979; Nunez et al., 1981; Rosini, 1976; Rossi, 1954; Schmid and Lenoir, 1980). Its introduction in starters has been considered, mixed with lactic acid bacteria, but up to now experimentation has been limited to the production of soft cheeses (Fatichenti et al., 1979; Yamauchi et al.,. 1976).

We have recently seen that $D e b$. hansenii, in conditions still to be completely determined, inhibits the germination of the spores of Clostridium tyrobutyricum and $\mathrm{Cl}$. butyricum by nutritional competition and through the production of exo- and endo-cellular metabolites (Fatichenti et al., 1983). As the germination of the clostridial spores depends on the presence of acetic and lactic acids in the cultural substrate (Bergère, 1969), a nutritional type of inhibition by $D e b$. hansenii appears likely. In fact, this yeast utilizes acetate and lactate in vitro as the sole sources of carbon (Ikemiya and Yasumy, 1973; Deiana et al., 1984).

With a view, therefore, of possibly using Deb. hansenii in cheese factories for making hard cheeses, the present work was undertaken to examine the capability of the yeast to degrade lactate and acetate directly in the cheese.

\section{MATERIALS AND METHODS}

The whole experiment was carried out on sheep milk during cheese making trials on an industrial scale to produce Pecorino Romano cheese.

\section{Starters}

The lactic acid bacteria starter was prepared with Streptococcus thermophilus (strain GF 13), Str. lactis (strain FOS 20) and Lactobacillus bulgaricus (strain FOS 3 ) and the yeast starter with Deb. hansenii (strain F3512). All strains came from the collection of the Istituto di Microbiologia Agraria e Tecnica, Sassari. After inoculation $(1 \%)$, in pasteurized whey $+10 \%$ milk, the Str. thermophilus and Lac. bulgaricus strains were incubated at $45^{\circ} \mathrm{C}$ for $12 \mathrm{~h}$ and Str. lactis at $35^{\circ} \mathrm{C}$ for $12 \mathrm{~h}$, and mixed together before use. The yeast cells were cultivated for $48 \mathrm{~h}$ at $25^{\circ} \mathrm{C}$ in 0.21 of liquid GYEP for trial A and 2.01 for trial B (GYEP $=1 \%$ glucose, $0,5 \%$ Difco yeast extract, $1 \%$ Difco peptone) washed, resuspended in physiological saline and then added to the milk for cheese making. 


\section{Cheese making trials}

Wheels of Pecorino Romano were produced in accordance with normal practice. After heating to $65^{\circ} \mathrm{C}$ for 2 minutes, the milk was cooled to $39^{\circ} \mathrm{C}$ and inoculated with the starters of lactic acid bacteria and yeast. The amount of lactic starter equalled $0.25 \%$. In order to check the action of the yeast, 3 trials were set up, each in 1000 litres of milk and distinguished thus:

$$
\begin{aligned}
& \text { Trial A }- \text { lactic starter }+10^{5} \text { yeast cells } / \mathrm{ml} \text { milk. } \\
& \text { Trial } \mathrm{B}-\text { lactic starter }+10^{6} \text { yeast cells } / \mathrm{ml} \text { milk. } \\
& \text { Trial } \mathrm{T}-\text { lactic (control) starter without yeast. }
\end{aligned}
$$

Curdling was effected by adding liquid sheep rennet. After being kept in a warm room (whey drainage), wheels were transferred to the curing room (maintained at $12-15^{\circ} \mathrm{C}$ ) where dry-salting also took place.

\section{Sampling and analyses}

Sampling of the milk in the cheese vat was done after heating at $65^{\circ} \mathrm{C}$ for 2 minutes followed by subsequent cooling at $39^{\circ} \mathrm{C}$ and before inoculation with the starters and sampling of the cheese after $1,10,30,60,90,150$ and $240 \mathrm{~d}$ of curing. Cheese samples were taken using sterile triers. Fig. 1 shows how the plugs E (external) and I (internal) were withdrawn from the cheese and it also shows the dimensions of the plugs (about $5 \mathrm{~cm}$ long each). Six portions of $\mathrm{E}$, taken from six different wheels of cheese belonging to the same trial, were mixed together and homogenized, thus forming the $\mathrm{E}$ composite sample used for analytical work. Six portions of I taken and treated in the same manner formed the I composite sample, also used for analytical work.

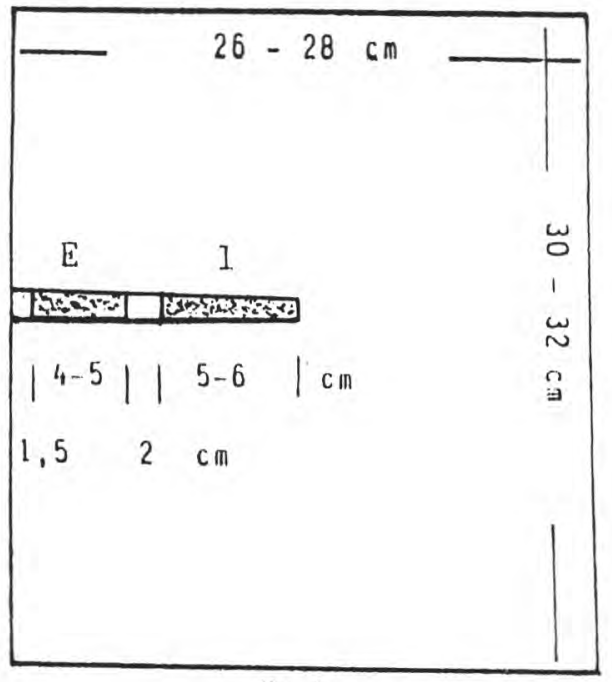

fig. 1

Cross section of a Pecorino Romano cheese: size and location of samples used for bacteriological and chemical analysis 
Microbiological analyses for coliforms, micrococcaceae, enterococci, mesophilic and thermophilic lactobacilli and streptococci, leuconostoc, propionibacteria, spores of Clostridium and Bacillus and finally yeast were made with the usual methods and culture media. The following determinations were made for both milk and cheese: $\mathrm{pH}$ - potentiometric method; lactose - reduction method; total nitrogen - Kjeldhal; L(+) lactic acid, D(-) lactic acid and acetic acid Boehringer enzymatic method (1982); non-casein nitrogen (NCN) Kjeldhal method on filtrate after precipitation at $\mathrm{pH} 4.6$; non-protein nitrogen (NPN) - Kjeldhal method on filtrate after precipitation with $12 \%$ TCA; dry substance - IDF official method; fat Soxhlet extraction with diethyl ether; free volatile fatty acids acidification of the cheese at $\mathrm{pH} 2.0$, extraction in a current of steam, titration with $0.1 \mathrm{~N} \mathrm{NaOH}$; free non-volatile fatty acids - Soxhlet extraction of residue of free volatile fatty acids distillation with ether and hexane in equal proportions, titration with $0.1 \mathrm{~N} \mathrm{NaOH}$ (Massoni et al., 1983); casein residues - extraction by Albonico et al., (1966), and electrophoretical analyses on polyacrylamide gel as described by Resmini et al., (1971).

\section{RESULTS AND DISCUSSION}

The technological data of the experimental work are reported in Table 1. To avoid unecessarily complicating the diagrams, Fig. 2 does

\section{TABLE 1}

Technological data of the experimental work (the data were the same for the three batches A, B, T)

\begin{tabular}{l|c}
\hline \multicolumn{1}{c|}{ Data } & \\
\hline & \\
Milk acidity & $7^{\circ} .5 \mathrm{SH} \%$ \\
Milk pH & 6.34 \\
Heat treatment of milk & $65^{\circ} \mathrm{C} \mathrm{for} 2 \mathrm{~min}$. \\
Lactic starter acidity & $20^{\circ} \mathrm{SH}$ \\
Lactic starter pH & 4.15 \\
Percentage (v/v) of starter added to milk & 0.25 \\
Amount of liquid sheep rennet for 1000 1 of milk & $185 \mathrm{ml}$ \\
Curdling temperature & $39^{\circ} \mathrm{C}$ \\
Curdling time & $16 \mathrm{~min}$. \\
Curd cutting time & $5 \mathrm{~min}$. \\
Cooking & $45^{\circ} \mathrm{C}$ for $5 \mathrm{~min}$. \\
Whey acidity & $4^{\circ} .5 \mathrm{SH} \%$ \\
Whey pH & 6.13 \\
Warm room (whey drainage) & $32^{\circ} \mathrm{C}$ for $6 \mathrm{~h}$ \\
& \\
\hline
\end{tabular}




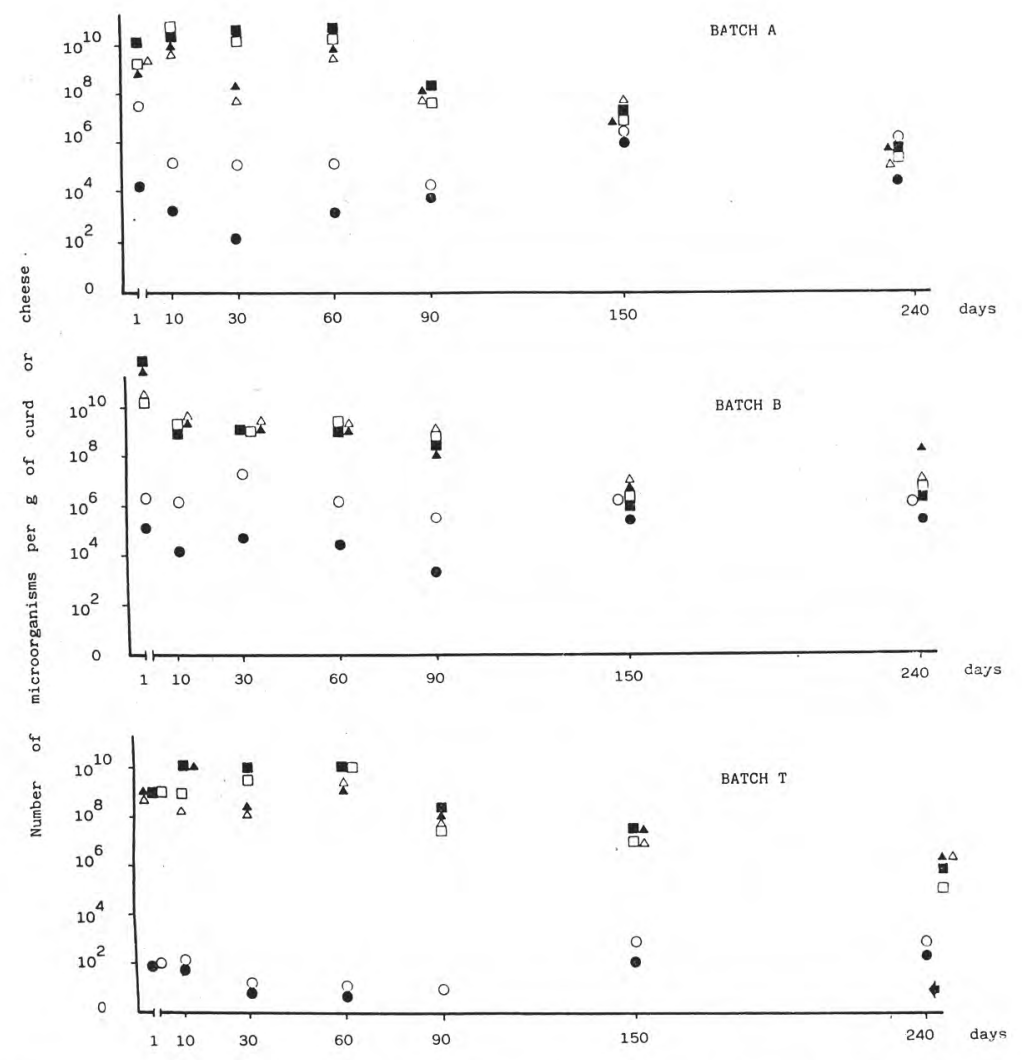

Thermophilic lactobacilli $=\mathrm{I}, \mathrm{L} \mathrm{E}$; thermophilic streptococci $\Delta \mathrm{I}, \triangle \mathrm{E}$; yeast $\bullet \mathrm{I}, \mathrm{O}$.

fig. 2

Development of microflora in the production of Pecorino Romano

not show the evolution during cheese ripening of all the organisms found in the microbiological analyses, but only the yeast and thermophilic lactic microflora. Tables 2 and 3 report the results of the chemical analyses of the milk and cheese.

Graphs showing the course of total lactic acid, L(+) lactic acid, $\mathrm{D}(-)$ lactic acid, acetic acid and volatile and non-volatile fatty acids are given in Figs. 3, 4, 5, 6 and 7 respectively. Plates $1-3$ show the results of the electrophoretic analyses of the casein residues at 1,10 , $30,60,90,150$ and $240 \mathrm{~d}$ of ripening (internal sampling). 
$T A B L E 2$

Analysis of milk and cheese during ripening of Pecorino Romano.

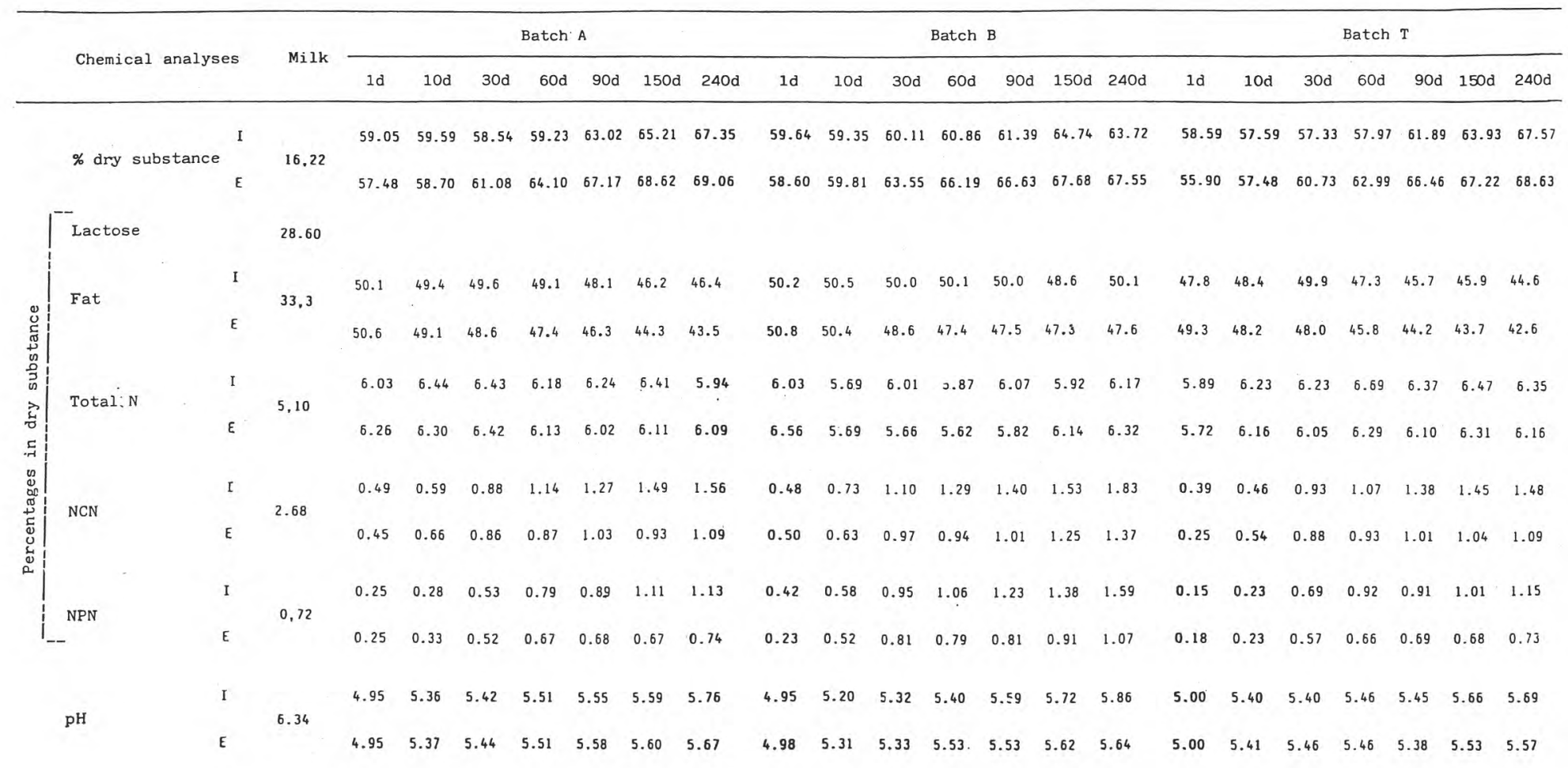




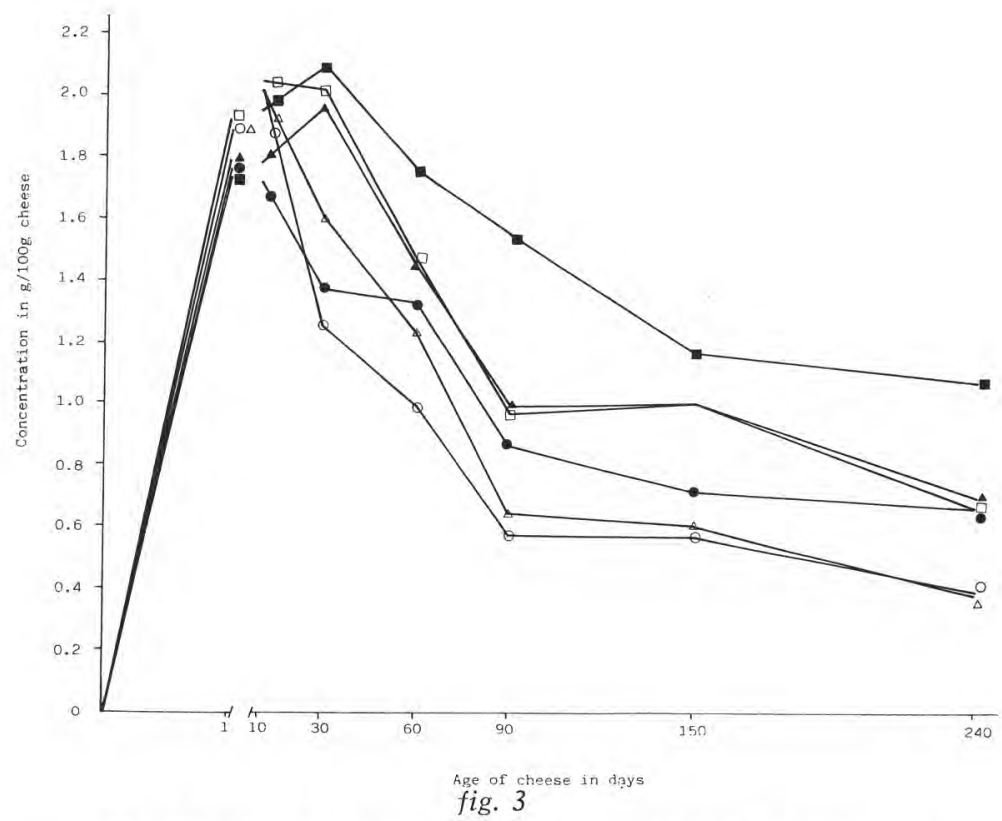

Total lactic acid formation in ripening Pecorino Romano

$\Delta$ internal batch $\mathrm{A} ; \triangle$ external batch $\mathrm{A}$; - internal batch $\mathrm{B}$; $O$ external batch $\mathrm{B}$;

1. internal batch $\mathrm{T}$; $\square$ external batch $\mathrm{T}$

\section{Microbiological analyses}

The addition of lactic acid bacteria as whey starter caused a marked development of the mesophilic and thermophilic lactic microflora. In general, these microorganisms were found in similar numbers whether in the internal part of the wheels or the external.

In general, the microflora reached a maximum at 10 and $30 \mathrm{~d}$ of ripening; the relationship between streptococci and lactobacilli remained more or less constant at all times.

The yeast inoculated in the milk of trial batches $\mathrm{A}$ and $\mathrm{B}$ developed well (up to $10^{6}$ and $10^{7}$ ) and was superior to that in batch $\mathrm{T}$ (no more than 103). Collateral microbiological tests showed that the yeast which developed in batches A and B almost entirely consisted of the Deb. hansenii inoculated, whereas in batch $\mathrm{T}$ various species had developed, mainly of the genera Rhodotorula, Debaryomyces and Candida. It was noted in particular that, in several instances after a certain initial development, yeast growth became static at around 3 months and then resumed in subsequent assays. The yeast populations were generally more numerous in the external part (average $\sim 10^{6}$ ) of the cheese wheel than in the internal part (average $\sim 10^{3}$ in $\mathrm{A}$ and $10^{4}$ in $\mathrm{B}$ ). 


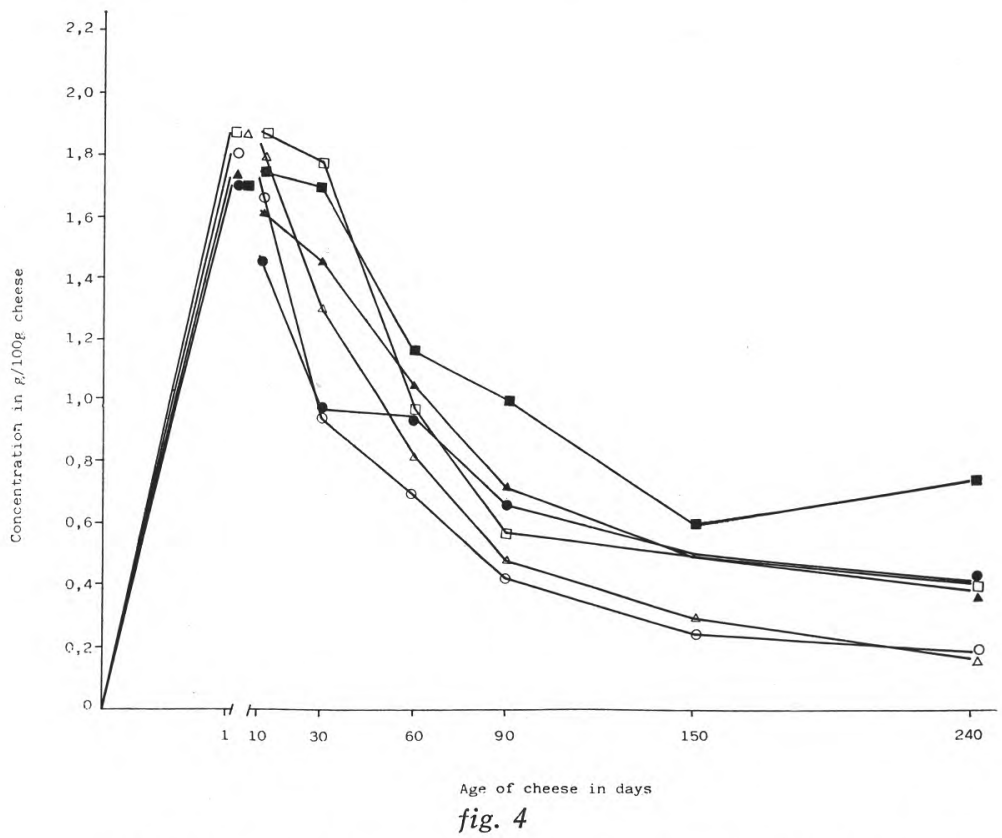

$\mathrm{L}(+)$ lactic acid formation in ripening Pecorino Romano

$\Delta$ internal batch A; $\triangle$ external batch A; $\bullet$ internal batch B; 0 external batch $\mathrm{B}$;

- internal batch T; $\square$ external batch T

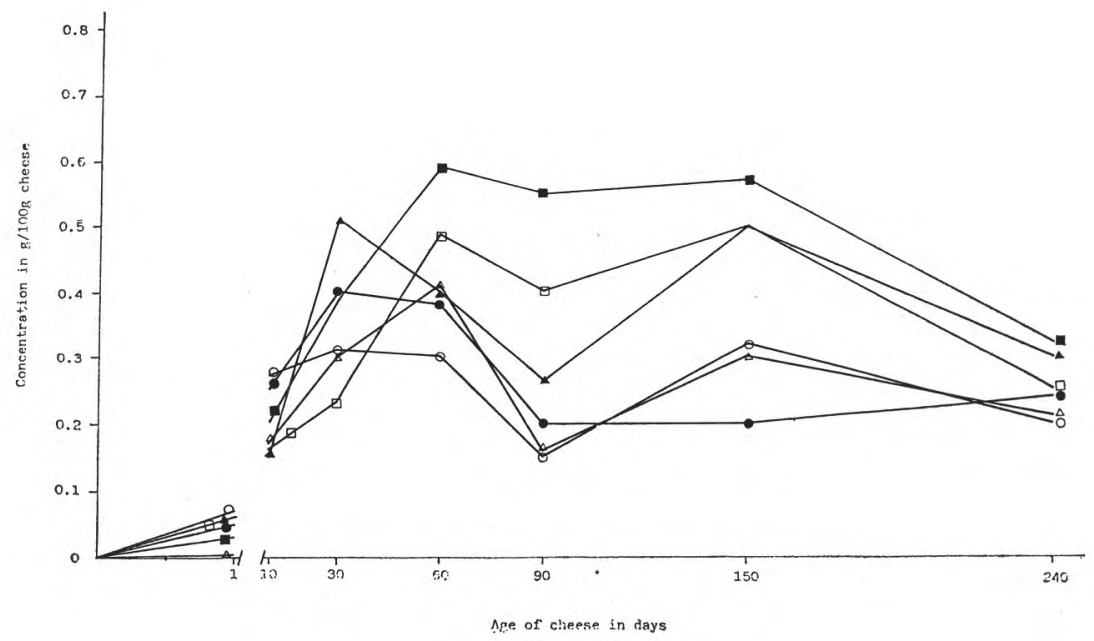

fig. 5

$\mathrm{D}(-)$ lactic acid formation in ripening Pecorino Romano

$\Delta$ internal batch A; $\triangle$ external batch A; $\bullet$ internal batch $\mathrm{B}$; 0 external batch $\mathrm{B}$;

- internal batch T; $\square$ external batch T 


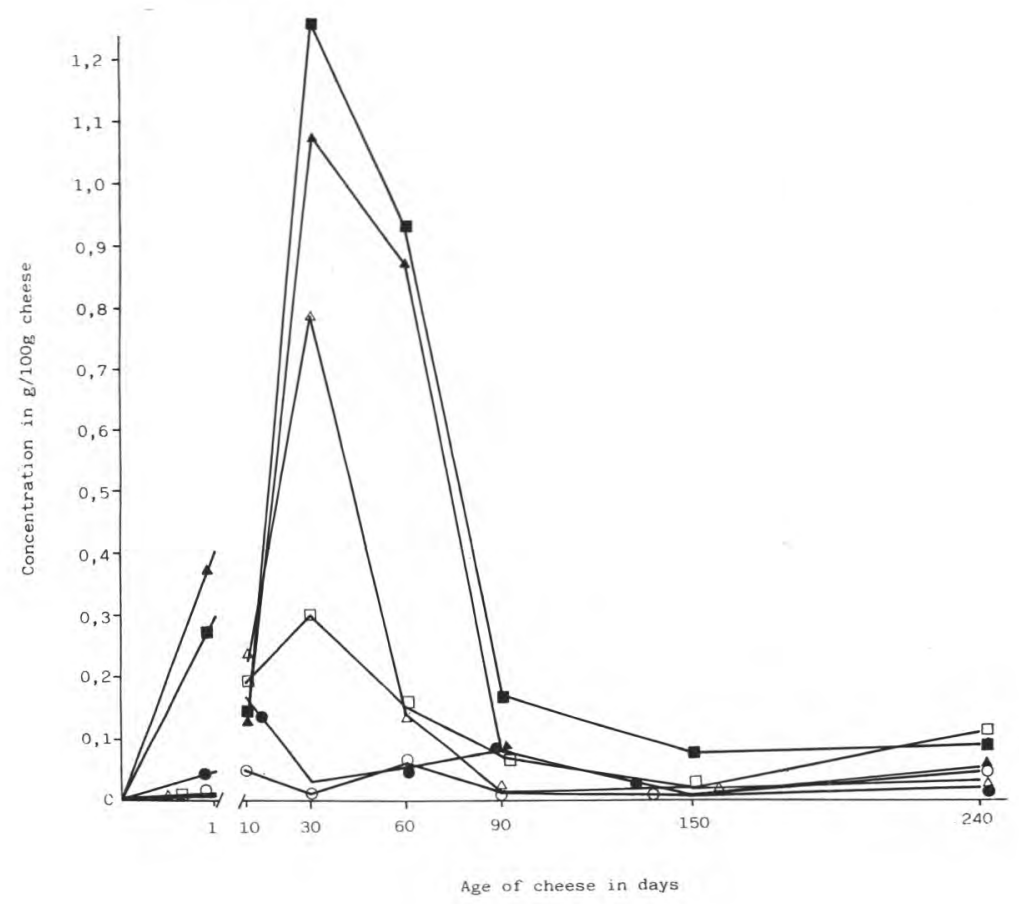

fig. 6

Acetic acid formation in ripening Pecorino Romano

$\Delta$ internal batch A; $\triangle$ external batch A; internal batch B; 0 external batch $\mathrm{B}$;

- internal batch T; $\square$ external batch T

\section{Chemical analyses}

The results of the chemical analyses performed on the cheeses in the three trial batches at various ripening times and mentioned in table 2 show no significant differences between the external and internal parts of the cheese. That is, all cheeses ripened normally. A fairly substantial increase in the values of NCN and NPN throughout ripening was, however, recorded for batch $\mathrm{B}$, both in the external and internal parts. Probably, with the larger amount of yeast in the starter a cheese was obtained in which proteolysis, and therefore ripening, was accelerated.

The electrophoretic patterns showed no substantial differences among the three trial batches, nor between the external and internal sampling in the separate batches; plates 1-3, therefore, only refer to internal sampling.

$L(+)$ lactic acid: Fig. 4 shows that in the initial stages of ripening $(1$ and $10 \mathrm{~d}) \mathrm{L}(+)$ lactic acid concentrations were higher towards the edge of the cheese, a phenomenon also seen in Gruyere and 


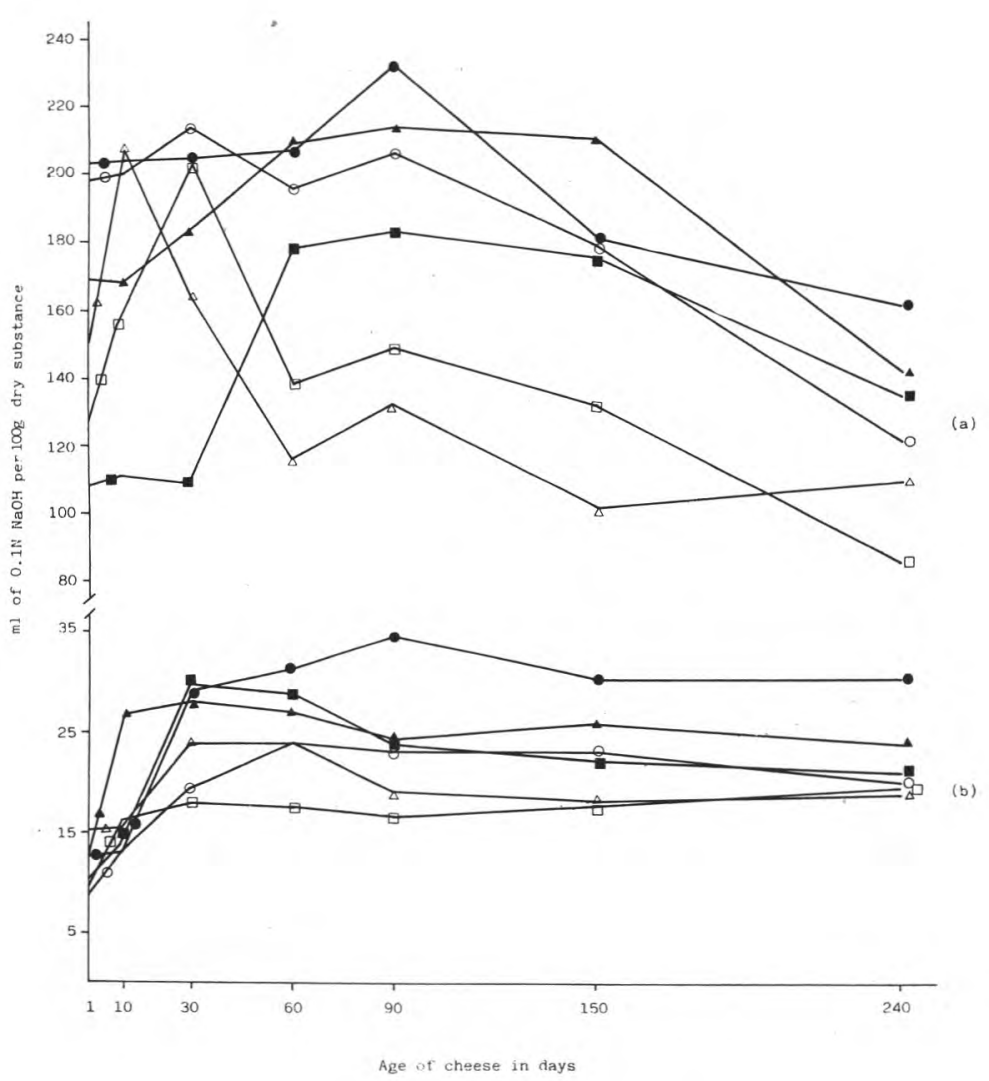

fig. 7

(a) Free non-volatile and (b) free volatile fatty acids during ripening of Pecorino Romano

$\Delta$ internal batch A; $\triangle$ external batch A; $\bullet$ internal batch $\mathrm{B}$; O external batch $\mathrm{B}$;

- internal batch T; $\square$ external batch T

Emmental (Accolas et al., 1978; Mocquot, 1979; Steffen, 1975) and probably of common occurence. As ripening proceeded however, the $\mathrm{L}(+)$ lactic acid started to decrease and the decrease in concentration, from 10 days onwards, was particularly rapid between 30 and 60 days. However L(+) lactic acid remained at a higher concentration in the internal part than in the external, this being due most likely to the more rapid consumption of lactate by the moulds and bacteria which developed on the surface. Also the lactate consumption was more noticeable in the cheeses prepared with yeast in the starter. 


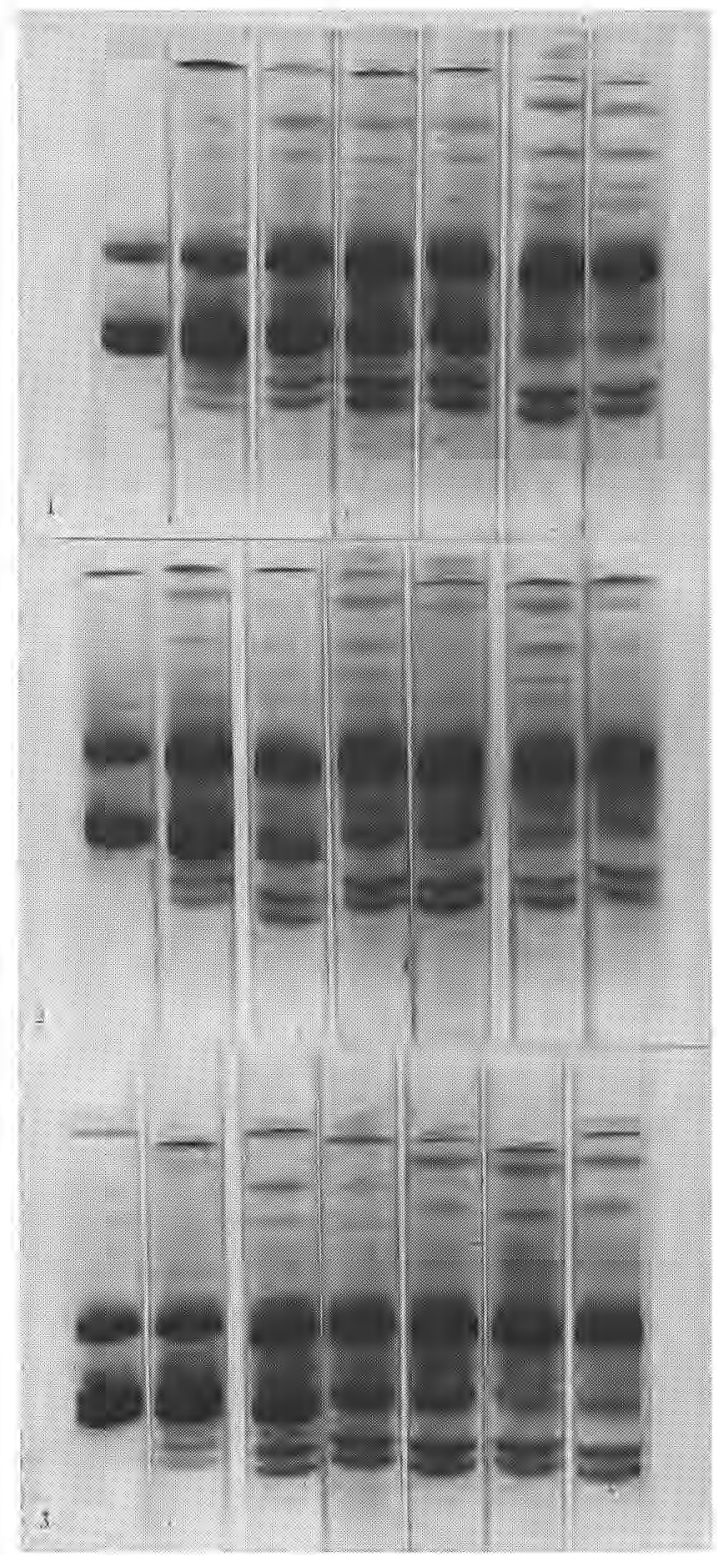

Plates $1-3$

Electrophoretic analyses of casein residues at $1,10,30,60,90,150$ and $240 \mathrm{~d}$ of ripening. 1, batch A (internal); 2 , batch $\mathrm{B}$ (internal); 3, bach $\mathrm{T}$ (internal) 
The consumption of $\mathrm{L}(+)$ lactate can be more easily seen by examining the data starting from $10 \mathrm{~d}$ of ripening (Tab. 3).

TABLE 3

Percentage of $\mathrm{L}(+)$ Lactic acid.

\begin{tabular}{ll|l|l|l|l|l|l}
\hline & & $10 \mathrm{~d}$ & $30 \mathrm{~d}$ & $60 \mathrm{~d}$ & $90 \mathrm{~d}$ & $150 \mathrm{~d}$ & $240 \mathrm{~d}$ \\
\hline Batches & & & & & & & \\
\hline $\mathrm{A}$ & & & & & & & \\
$\mathrm{B}$ & $\mathrm{I}$ & 1,63 & 1,45 & 1,05 & 0,72 & 0,50 & 0,39 \\
$\mathrm{~T}$ & & 1,75 & 0,97 & 0,95 & 0,66 & 0,51 & 0,42 \\
& & 1,70 & 1,16 & 1,00 & 0,60 & 0,75 \\
$\mathrm{~A}$ & $\mathrm{E}$ & 1,84 & 1,30 & 0,82 & 0,48 & 0,30 & 0,17 \\
$\mathrm{~B}$ & 1,73 & 0,94 & 0,69 & 0,42 & 0,25 & 0,19 \\
$\mathrm{~T}$ & & 1,88 & 1,78 & 0,97 & 0,57 & 0,50 & 0,41 \\
\hline
\end{tabular}

As can be seen, the fall in $\mathrm{L}(+)$ lactic acid concentration during ripening was greater in batches $\mathrm{A}$ and $\mathrm{B}$ than in the control T. By averaging the data I (from internal sampling) for all three batches and comparing the resulting average percentages with those similarly obtained for data E (from external sampling), it can also be seen how the difference between $\mathrm{I}$ and $\mathrm{E}$ lactic acid concentrations gradually increased from $10 \mathrm{~d}$ onwards, except for the last two assays. These average percentage differences were $-0,60,+0,10,+0,68$, $+0,91,+0,56$, and $+0,79$ for $10,30,60,90,150$ and $240 \mathrm{~d}$ respectively.

$D$ (-) lactic acid: (Fig. 5). At the beginning of the ripening period, D(-) lactic acid concentrations were low (1 and 10 d). They then progressively increased to a maximum at between 30 and $60 \mathrm{~d}$, that is during the period where the decrease in $\mathrm{L}(+)$ was most rapid. After this there was a decrease starting at about $90 \mathrm{~d}$. Although not supported by statistical analysis to confirm the significance of these results this behaviour may be similar to the one observed by Turner et al. (1983). To explain the fact that the $\mathrm{D}(-)$ lactic acid is still increasing when $\mathbf{L}(+)$ is rapidly decreasing these authors, working on a Swiss type cheese, suggest that racemization may occur during the course of cheese ripening.

Along the same line, some of us have observed in another work (Deiana et al., 1984) that Deb. hansenii preferentially utilized the $\mathrm{L}(+)$ lactate isomer.

Total lactic acid. Fig. 3 represents the sum of the $\mathrm{L}(+)$ and $\mathrm{D}(-)$ lactic acids and its course is roughly similar to that of $\mathrm{L}(+)$ lactic acid, except that the decrease in lactic acid concentration takes place 
somewhat later (between 30 and 60 days instead of 10 to 30 days) and is less pronounced than in the case of $L(+)$. This is because the increase of $\mathrm{D}(-)$ between 30 and 60 days compensates to a certain extent the decrease of $\mathrm{L}(+)$ during the same period. The fall in total lactic acid concentration during ripening is also greater in batches $\mathrm{A}$ and $\mathrm{B}$ than in the control $\mathrm{T}$, particularly in $\mathrm{B}$ where more yeast was inoculated.

Free volatile and non-volatile fatty acids. The quantitative analysis (Fig. 7) of the various samples from the three trial batches showed that development was not the same. The yeast inoculated cheeses, particularly batch B, constantly revealed higher fatty acid values than the control batch - a result even more in evidence towards the internal part of the cheese.

Acetic acid: The values for acetic acid (Fig. 6) also showed certain peculiarities. In general, however, there was an initial increase with a maximum at $30 \mathrm{~d}$, followed by rapid diminution up to $90 \mathrm{~d}$, reaching minimum values at $150 \mathrm{~d}$. Batch $\mathrm{B}$, with a higher yeast content, produced the lowest values. Apart from some exceptions, internal samplings showed higher acetic acid concentrations than external ones.

Organoleptic tests: In the first phases of ripening, all cheese wheels had a compact and homogeneous structure, with slight «eyeing" in batch T; flavour and colour were normal throughout. At the end of ripening, the wheels had a good, firm texture, (the T batch showing slight flakiness); they were pale straw-coloured; in all cases, flavour was characteristic and aroma typically pleasant.

\section{CONCLUSIONS}

The addition of a selected culture of Deb. hansenii to the lactic starter in the production of Pecorino Romano cheese gave good results for a number of reasons, which can be summarized as follows:

1. The yeast developed well in both the external and internal parts of the cheese wheels. times.

2. Proteolysis was quicker, thus accelerating overall ripening

3. Production of volatile and-non volatile fatty acids was also quicker and a greater amount of these acids was liberated in the internal part of the wheels than in the external part (most striking in batch B).

4. It was clear, from the first ripening phase, that diminution in lactic acid was greater where the yeast had developed, particularly in batch $\mathrm{B}$ which had been inoculated with a greater number of yeast cells. 
5. Acetic acid, found in higher concentrations in the interior of the wheels, was also greatly reduced where the yeast cells were more numerous.

The introduction of Deb. hansenii did not cause any deterioration in the quality of the finished product; it did, in some measure, accelerate ripening. The more rapid consumption of lactic and acetic acids, with a higher production of free fatty acids, in the trial batch inoculated with a greater number of yeast cells lends weight to the hypothesis that in this way Deb. hansenii may inhibit the development of clostridial spores. We would emphasise, however, that the results are based on one experiment and that some of the differences discussed are not statistically significant. Further experimentation is required, therefore, to verify our hypothesis.

\section{References}

Accolas (J. P.), Veaux (M.), Vassal (L.), Mocouot (G.). 1978. - Evolution de la flore lactique thermophile au cours du pressage des fromages à pâte cuite. Le lait, 58, 118-132.

Albonico (F.), Gianani (L.), Resmini (P.), Zanini (A.) (1966). - Studi sui latti di diverse sepecie. Industria del Latte, 2, 104-110.

BERGÈRE (J. L.) (1969). - La germination de la spore de Clostridium tyrobutyricum. I. Action de différents composés sur la phase initiale. Annales de l'Institut Pasteur, 117, 179-195.

Boemringer ManNheim. - Methods food analysis (1981-1982).

Deiana (P.), Fatichenti (F.), Farris (G. A.) (1977).- Indagini microbiologiche sul latte e sul formaggio di capra in Sardegna. Nota I. I lieviti. Industria del Latte, 13, 49-56.

Deiana (P.), FATICHENTI (F.), FARRIS (G. A.) (1983). - Utilizzazione dell'acido lattico da parte di alcuni stipiti di Debaryomyces hansenii in crescita aérobica e anaerobica a diversi livelli di temperatura. Industria del Latte (in press).

Devoyod (J. J.), Sponem (D.) (1970). - La flore microbienne du fromage de Roquefort. Le Lait, 50, 524-543.

Fatichenti (F.), Bergère (J. L.), Deiana (P.), Farris (G. A.) (1983). - Antagonistic activity of Debaryomyces hansenii towards Clostridium tyrobutyricum and Clostridium butyricum. Journal of Dairy Research, 50, 499-507.

Fatichenti (F.), Deiana (P.), Farris (G. A.), Campus (R.), Vodret (A.), Carini (S.), Todesco (R.) (1979). - Impiego di uno starter misto di fermenti lattici e lieviti in una nuova tecnologia di fabbricazione di formaggio di capra a pasta molle. Industria del Latte, 15, 13-32.

Fatichenti (F.), Farris (G. A.), Deiana (P.) (1977). - L'evoluzione del la microflora blastomicetica nel Fiore Sardo. Industria del Latte, 13, 11-18.

GEorgantas (S.) (1979). - The blastomycetic flora during the ripening of Teleme cheese. Milchwissenschaft, 34, 24-27.

IKEMTYA (M.), YASUMI (K.) (1973). - A strain of Debaryomyces hansenii isolated from processed cheese. Journal of Fermentation Technology, 51, 761-767.

Massoni (F.), Dallavalle (M. G.), Lodi (R.) (1983). - Impiego di coagulante e lipasi d'origine microbica nella produzione di provolone. Industria del latte, 19, 3-16. 
Mocouot (G.) (1979). - Reviews of the progress of Dairy Science: Swiss-type cheese. Journal of Dairy Research, 46, 133-160.

Nunez (M.), Medina (M.), Gaya (P.), Dias-Amado (C.) (1981). - Les levures et les moisissures dans le fromage bleu de Cabrales. Le Lait, 61, $62-79$.

Resmini (P.), Volonterio (G.), Saracchi (S.), Annibaldi (S.) (1971). - Esperienze di fabbricazione di formaggio Parmigiano Reggiano con enzima «Suparen». Nota II. Sci. Tec. Latt. Casear., 22, 406-425.

Rosini (G.) (1976). - I lieviti in Formaggi «Pecorino» ottenuti con cagli tradizionali e microbici. Ann. Fac. Agr. Univ. Perugia, 31, 433-442.

Rossi (J.) (1954). - I lieviti del latte e dei latticini. Nota I. Ann. Fac. Agr. Univ. Perugia, 10, 46-49.

Schmidt (J. L.), Lenorr (J.) (1980). - Contribution à l'étude de la flore levure du fromage de Camembert. Le Lait, 60, 272-282.

STEFFEN (C.) (1975). - Enzymatische Bestimmungsmethoden zur Erfassung der Gärungsvorgänge in der milchwirschaftlichen technologie. Lebensmitt. Wiss. und-Techn., 8, 1-16.

Turner (K. W.), Morris (H. A.), Martley (F. G.) (1983). - Swiss-type cheese II. The Role of Thermophilic Lactobacilli in Sugar Fermentation. New Zeland Journal of Dairy Science and Tecnology, 18, 117-123.

Yamauchi (K.), Kang (K. H), Kaminogawa (S.) (1976). - Proteolysis by Debaryomyces hansenii and lactic starters in skimmilk culture. Jap. J. Zootech. Sci., 47 (1), $12-17$. 